\title{
Late autumn condition of Calanus finmarchicus in the northwestern Atlantic: evidence of size-dependent differential feeding
}

\author{
Pierre Pepin ${ }^{1, *}$, Christopher C. Parrish ${ }^{2}$, Erica J. H. Head ${ }^{3}$ \\ ${ }^{1}$ Fisheries and Oceans Canada, Northwest Atlantic Fisheries Centre, PO Box 5667, St. John's, Newfoundland A1C 5X1, \\ Canada \\ ${ }^{2}$ Ocean Sciences Centre, Memorial University of Newfoundland, St. John's, Newfoundland A1C 5S7, Canada \\ ${ }^{3}$ Fisheries and Oceans Canada, Bedford Institute of Oceanography, PO Box 1006, Dartmouth, Nova Scotia B2Y 4A2, Canada
}

\begin{abstract}
We report size, lipid sac volume and fatty acid composition of C5 copepodites of Calanus finmarchicus collected in late autumn 2007 on the Newfoundland Shelf and in slope waters in the Labrador Sea, to assess differences in feeding histories between these populations. Copepodites from the slope waters were generally relatively large and were mainly at depth and in diapause, whereas those from shelf waters were relatively small and were either in the surface layers or had only recently descended into the deeper layer. Multivariate analyses revealed a strong pattern of separation among the levels of saturated fatty acids (SFA), monounsaturated fatty acids (MUFA) and polyunsaturated fatty acids (PUFA), bacterial fatty acid markers and $\omega 3$ PUFAs in copepods from the different areas. There was clear separation of diatom $(16: 1 \omega 7,16: 4 \omega 1$ and 20:5 13$)$ from prymnesiophyte-dinophyte $(18: 1 \omega 9,18: 4 \omega 3$ and 22:6 13$)$ fatty acid markers. Larger body size and greater energy reserves were associated with C5 C. finmarchicus from the slope waters and with increases in the proportion of fatty acid biomarkers for diatoms and omnivory. Smaller body sizes were associated with C5s on the shelf and with a greater proportion of fatty acid biomarkers for dinoflagellates and prymnesiophytes. C. finmarchicus collected near the coast had significantly higher levels of biomarkers indicative of terrestrial input in their diet.
\end{abstract}

KEY WORDS: Calanus finmarchicus $\cdot$ Fatty acids $\cdot$ Biomarkers $\cdot$ Diatoms $\cdot$ Dinoflagellates $\cdot$ Spatial segregation • Trophic relationships

\section{INTRODUCTION}

Throughout the north Atlantic, the calanoid copepod Calanus finmarchicus is a dominant species and a key contributor to secondary production (Mauchline 1998). Over-wintering stages, mostly copepodite stage 5 (C5), are located in the deep ocean basins (e.g. Labrador Sea, Norwegian Sea) at median depths ranging from 500 to 1500 m (Heath et al. 2004, Head \& Pepin 2008a). They emerge from dormancy prior to the onset of the spring phytoplankton bloom, moult, mate and migrate to the surface to feed and reproduce, with their offspring feeding and developing until late summer or early autumn. Some emergent individuals and their offspring are transported onto continental shelves while most remain over the deep basins (Harms et al. 2000, Edvardsen et al. 2003, Torgersen \& Huse 2005, Johnson et al. 2006). After hatching, individuals from the new generation (G1) develop through 6 naupliar and 5 copepodite stages, at which time most undertake an ontogenetic downward vertical migration and enter diapause as stage C5. Some continue development to moult into the adult copepodite (C6) stage to start production of a second generation (G2; Gislason \& Astthorsson 1996, Pasternak et al. 2001, Arashkevich et al. 2004). Individuals produced on the continental shelf 
are generally unlikely to find appropriate environments in which to survive the prolonged over-wintering period, although some shelf basins and channels, where the circulation is favourable, may allow diapausing populations to over-winter at depths between 200 and $400 \mathrm{~m}$ (e.g. Emerald Basin on the Scotian Shelf: McLaren et al. 2001; Laurentian Channel in the Gulf of St. Lawrence: Plourde et al. 2001; Gulf of Maine: Durbin et al. 2000).

In the northwest Atlantic, the Labrador Sea and the adjacent continental shelves are areas with high densities of Calanus finmarchicus (Planque \& Batten 2000). In late autumn (November to December), an average of $76 \%$ of the population of $C$. finmarchicus is in the C5 stage, with approximately $10 \%$ as $\mathrm{C} 4$ s and similar proportions as adults (average 5:1 female:male ratio; P. Pepin unpubl. data). At the same time, $>90 \%$ of the C5s in slope waters off the Grand Banks and Newfoundland Shelf are located at depths in excess of $200 \mathrm{~m}$ (Head \& Pepin 2008a), suggesting that most have entered dormancy, although on the continental shelf 55 to $94 \%$ (average $76 \%$ ) of the population are still in the top $100 \mathrm{~m}$ of the water column (Pepin \& Head 2009). Throughout the region, food resources available to copepods vary spatially and seasonally. The onset of the spring phytoplankton bloom progresses from south to north, with peaks in April on the northern Grand Banks, in May/June on the Labrador Shelf and in June/July in the central Labrador Sea (Pepin et al. 2008, Head et al. in press). Diatoms are numerically dominant during the spring bloom but form only a small portion of the phytoplankton community during the summer and autumn, when flagellates and dinoflagellates are numerically more abundant. Spatially, diatoms are relatively more abundant in waters of the Labrador Sea and Shelf, whereas dinoflagellates are more significant members of the phytoplankton community on the southern Newfoundland Shelf and Grand Banks throughout much of the year (Pepin et al. 2003). Also, Phaeocystis sp., a colonial prymnesiophyte, is often common in areas of high chlorophyll concentration in the central basin and in eastern regions of the Labrador Sea (Head et al. 2000, Stuart et al. 2000).

Development rates and body size at moult in Calanus finmarchicus are principally determined by temperature (Corkett et al. 1986, Campbell et al. 2001), which, in combination with feeding history, affects growth rates, sizes-at-stage and the accumulation of energy reserves. The wax ester reserves that are accumulated in late-stage copepodites consist primarily of

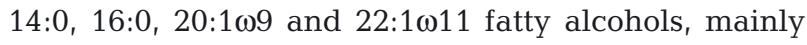
formed de novo by the copepods from non-lipid dietary precursors, and fatty acids of dietary phytoplankton origin (Sargent \& Falk-Petersen 1988, Miller et al.
1998). Previous work has demonstrated that fatty acids specific to diatoms, dinoflagellates, prymnesiophytes, ciliates, detritus and metazoans can be used to provide a qualitative assessment of the contribution of these different prey to the diet of herbivorous zooplankton (reviewed by Dalsgaard et al. 2003). Such markers may also allow us to determine whether the differences in body size and energy reserves of copepods from different environments are associated with differences in food type, as well as temperature. If there are differences among individuals collected from different areas, then these, as well as the differences in size and energy reserves, may contribute to the fate of the copepods (e.g. dormancy and successful overwintering versus moulting and reproduction).

In this study, we report the fatty acid composition of C5 Calanus finmarchicus copepodites collected in late November to early December 2007 from the Grand Banks and Newfoundland Shelf as well as from slope waters of the Labrador Sea and northwest Atlantic. Our objective was to assess whether C5 C. finmarchicus collected at different locations show evidence of differential growth and whether this is associated with feeding on different food sources. On the Newfoundland Shelf in November/December, a large proportion of the C5 population is in the surface layer, and will likely moult into adults (Head \& Pepin 2008b, Johnson et al. 2008), and even those C5s near the bottom have probably descended only recently (Pepin \& Head 2009). By contrast, most C5s are at depth and are in diapause in the waters along the slope and beyond (Head \& Pepin 2008a, Pepin \& Head 2009). Based on the region's seasonal cycles of temperature and phytoplankton taxonomic composition, we would expect individuals spawned earlier in the year or from more northerly locations to be larger (as a result of development at lower temperature), to have greater energy reserves for a given body size (as a result of having fed at higher phytoplankton concentrations), and to have a greater proportion of diatom markers than individuals produced later in the year.

\section{MATERIALS AND METHODS}

Sample collection. Zooplankton samples were collected on the continental shelf and slope east of Newfoundland, Canada, between 22 November and 5 December 2007 as part of the Atlantic Zone Monitoring Program. Stations were located either in the inner or outer branches of the Labrador Current (Fig. 1). Samples were collected using a $0.75 \mathrm{~m}$ ring net fitted with a $202 \mu \mathrm{m}$ mesh mounted on a dual net frame which was towed vertically from $5 \mathrm{~m}$ above bottom, to a maximum of $1000 \mathrm{~m}$, at $1 \mathrm{~m} \mathrm{~s}^{-1}$. The use of vertically integrated 


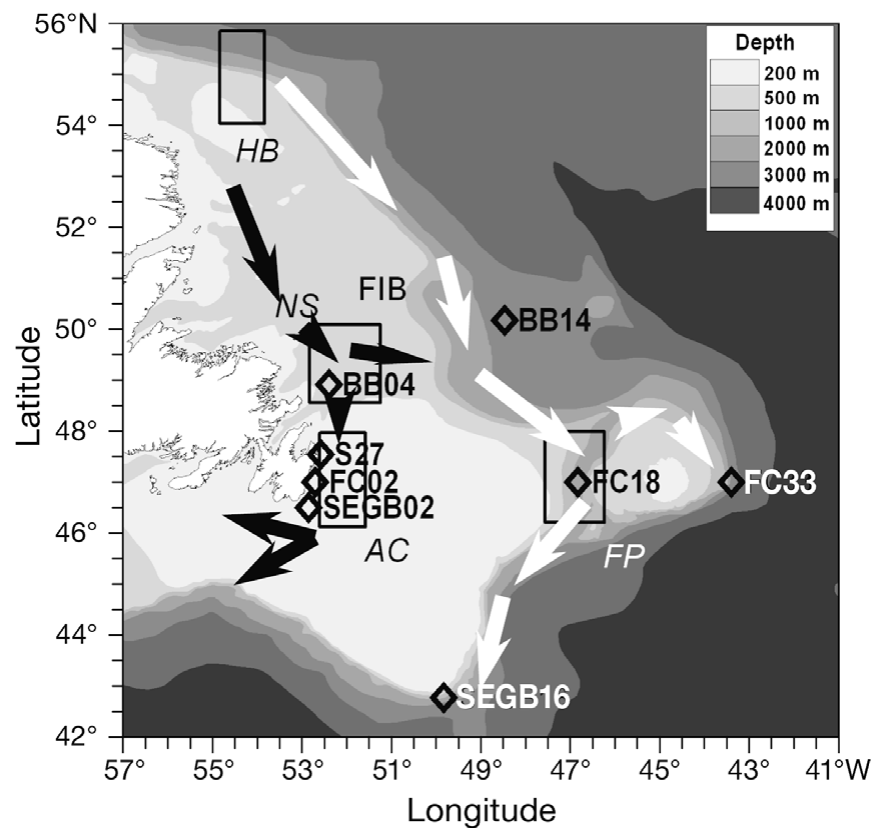

Fig. 1. Grand Banks, Flemish Cap and Newfoundland Shelf showing sampling locations and station identifiers (diamonds). Schematic representations of the inner and outer branches of the Labrador Current are shown as black and white arrows, respectively. The boxes represent the areas (AC: Avalon Channel $_{i} F P$ : Flemish Pass; HB: Hamilton Bank; NS: Newfoundland Shelf) for which satellite derived estimates of average sea surface temperature, based on $2 \mathrm{wk}$ intervals, are presented in Fig. 6. The box for the central Labrador Sea $\left(56^{\circ} 37.6^{\prime} \mathrm{N}\right.$, $53^{\circ} 10.1^{\prime} \mathrm{W}$ to $58^{\circ} 7.6^{\prime} \mathrm{N}, 50^{\circ} 24.9^{\prime} \mathrm{W}$ ) is not shown. Also shown is the location of Funk Island Bank (FIB; see 'Discussion'). Sample depths are BB04: 340 m; S27: 165 m; FC02: 180 m; SEGB02:

$180 \mathrm{~m} ;$ and $1000 \mathrm{~m}$ for BB14, FC18, FC33 and SEGB16

tows was not ideal but the contrast in the vertical distribution of C5s on and off the continental shelf is sufficiently large and consistent that samples from different areas reflect differences between populations that are primarily active (near-surface, shelf) and dormant (deep, slope: Head \& Pepin 2008a, Pepin \& Head 2009).

Zooplankton were sieved to remove seawater, placed in $2 \mathrm{ml}$ cryovials, sealed and stored at $-80^{\circ} \mathrm{C}$. To extract C5 Calanus finmarchicus, samples were partially thawed, placed on a cold plate and sorted as quickly as possible (<20 min). A high-resolution image of the lateral view of individual C5 was recorded using an Olympus Q-colour 5 RTV (5 megapixel) mounted on a dissecting stereo-microscope and linked to an Image Pro-plus V 6.0 image analysis system. For each specimen, prosome length (PrL) and lateral oil sac length (LOL) and area (LOA) were measured using the image analysis system. LOA was used as an index of energy reserves (Miller et al. 1998, 2000). For each sample, average PrL and LOA provided a measure of the body size and energy reserves. Ten specimens were placed at the bottom of a glass tube using a stainless steel probe and refrozen at $-80^{\circ} \mathrm{C}$. Utensils were cleaned between samples with filtered de-ionised water and wiped dry to minimise contamination. Only undamaged specimens (i.e. with no evidence of physical damage or with segmented oil sacs, which could indicate leakage) were included for analysis. This same procedure was used successfully by Pepin \& Head (2009) to describe the regional and seasonal variations in the distribution of energy reserves in C. finmarchicus. Five replicate sub-samples with 10 individuals were collected at 8 stations, but at 4 stations, 1 sub-sample did not yield reliable estimates of fatty acid composition owing to low lipid content and/or poor sample quality (S27, FC02, FC18, FC33), leaving us with a total of 36 sub-samples.

Lipid and fatty acid analysis. Lipids were extracted from Calanus finmarchicus using a modified Folch method (Parrish 1999). The test tube containing the frozen tissue in $2 \mathrm{ml}$ chloroform was allowed to thaw on ice before addition of $1 \mathrm{ml}$ of methanol. Samples were ground using a metal rod in $1 \mathrm{ml}$ of chloroform: methanol $(2: 1 \mathrm{v} / \mathrm{v})$, and $0.5 \mathrm{ml}$ of chloroform extracted water were then added. Homogenates were vortexed, sonicated for $4 \mathrm{~min}$ and centrifuged at $4000 \times g(2 \mathrm{~min})$ before the lower (chloroform) layer was removed by double pipetting. Three washes were made to maximise lipid recovery, and the chloroform layers were combined.

For a detailed study of fatty acids, samples were dried under $\mathrm{N}_{2}$, transesterified to methyl esters with $14 \%$ boron trifluoride and analysed as fatty acid methyl esters with an Agilent 6890 gas chromatograph (GC) equipped with an autoinjector and flexible fusedsilica column $(30 \mathrm{~m} \times 0.32 \mathrm{~mm}$ i.d. $\times 0.25 \mu \mathrm{m}$ film thickness) coated with polyethylene glycol (ZBwax; Phenomenex). To determine derivatisation efficiency, a few samples were analysed by thin layer chromatography/ flame ionisation detection (FID) before and after derivatisation. On average, $84 \%$ of the total acyl lipid class content was transesterified to methyl esters. The operation parameters for the GC were identical to those described by Budge \& Parrish (1998). Briefly, the flow rates for the carrier gases, viz. hydrogen, air and helium, were 2,300 and $30 \mathrm{ml} \mathrm{min}^{-1}$, respectively. The column temperature was programmed to hold at $65^{\circ} \mathrm{C}$ for $0.5 \mathrm{~min}$, then rise to $195^{\circ} \mathrm{C}$ and hold for $15 \mathrm{~min}$ after ramping at $40^{\circ} \mathrm{C} \mathrm{min}^{-1}$, and to hold at $215^{\circ} \mathrm{C}$ for $0.75 \mathrm{~min}$ after ramping at $2^{\circ} \mathrm{C} \mathrm{min}^{-1}$. The injector temperature increased from 150 to $250^{\circ} \mathrm{C}$ at $200^{\circ} \mathrm{C} \mathrm{min}{ }^{-1}$. The FID was kept at $260^{\circ} \mathrm{C}$ throughout the analysis. Fatty acids were identified by comparison of retention times with 4 commercial fatty acid standards (polyunsaturated fatty acid 1 [PUFA1], PUFA3, bacterial fatty acid methyl ester mix and 37-component) supplied by 
Supelco. Data were processed with the Varian Galaxie Chromatography Data System, version 1.9.3.2.

Statistical analysis. The average morphometrics of copepods from the different sampling locations were contrasted using analysis of variance (ANOVA), in which location (shelf versus slope) was treated as a categorical variable. Tukey's pairwise post hoc test was used to compare means among locations. The energy reserves of individual copepods from the different locations were contrasted using an analysis of covariance (ANCOVA), in which location (shelf versus slope) was treated as a categorical variable and PrL and LOA were continuous.

Fatty acid data are reported as mean $( \pm \mathrm{SD})$ proportion of total fatty acids. In several instances, many biomarkers may be used to identify prey. One might be tempted to choose a single marker as an ideal index, but this might raise the question that the choice of a single marker was intended to demonstrate a particular trend. To avoid any uncertainty in the reliability of our findings, we chose to use several markers whenever possible. We also performed comparisons of various biomarkers and/or indices of nutritional status. Individual fatty acids, their sums or ratios, were used as indicators of diatoms $(16: 1 \omega 7+16: 4 \omega 1+20: 5 \omega 3$; 16:1 $\omega 7 / 16: 0 ; \Sigma \mathrm{C}_{16} / \Sigma \mathrm{C}_{18}$ : Budge \& Parrish 1998, Dalsgaard et al. 2003), prymnesiophytes (18:1 $\omega 9+18: 4 \omega 3$ :

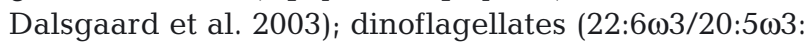
Budge \& Parrish 1998), carnivory $(18: 1 \omega 7 / 18: 1 \omega 9$ : Dalsgaard et al. 2003) and terrestrial input (18:2 $\omega 6+$

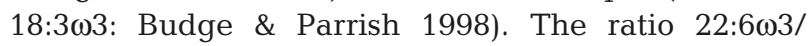
20:5 03 is also an important nutritional index (Sargent 1995, Shields et al. 1999), as is $\Sigma \omega 3 / \Sigma \omega 6$ (Sargent 1995, Milke et al. 2004). In addition, we included Parrish et al.'s (2005) polyunsaturated index of $\mathrm{C}_{16}$ fatty acids as a measure of the biochemical status of diatoms in the diet of Calanus finmarchicus: the ratio of $(16: 2 \omega 4+$ $16: 3 \omega 4+16: 4 \omega 3+16: 4 \omega 1)$ to $(16: 0+16: 1 \omega 7+16: 1 \omega 5+$

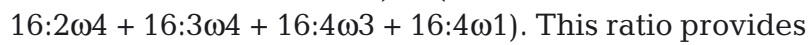
an index of nutrient sufficiency in diatoms and has been shown to decline rapidly as nitrate concentrations in the water column fall following the spring bloom (Parrish et al. 2005)

All statistical analyses were performed after arcsinesquare root transformation of proportions of individual fatty acids relative to total fatty acids and untransformed values of ratio indices. For comparative purposes, samples were grouped by location, either on the continental shelf or in slope waters. A 2-sided Student's $t$-test with unequal variance was used to compare the proportion of individual fatty acids between locations. We also applied the 2-sided Student's $t$-test with unequal variance to the grouping based on a Tukey post hoc test of average PrL by location determined from the ANCOVA of morphometric characteristics.
To assess which elements contributed to the differentiation among samples, separate principal components analyses were performed on fatty acid categories (bacterial, saturated -SFA, monounsaturated -MUFA, polyunsaturated -PUFA and $\omega 3$ fatty acids) as well as on the composition of individual fatty acids that exceeded an average of $1 \%$ of total fatty acids. This ensured that potentially important fatty acids were not excluded from the analysis. Performing our analyses with only fatty acids with an overall average exceeding $2 \%$ contribution to the total fatty acids did not affect our findings or conclusions. Pearson product-moment correlation coefficients were used to assess the relationships between fatty acid composition, biomarkers and principal component scores with PrL or LOA.

\section{RESULTS}

The integrated abundance of C5 Calanus finmarchicus at stations on the continental shelf (BB04: $11600 \mathrm{~m}^{-2}$; S27: $4200 \mathrm{~m}^{-2}$; FC02: $5200 \mathrm{~m}^{-2}$; SEGB02: $13500 \mathrm{~m}^{-2}$ ) was on average 3 times less than that found in slope waters (BB14: $21700 \mathrm{~m}^{-2}$; FC18: $32000 \mathrm{~m}^{-2}$; FC33: $10600 \mathrm{~m}^{-2}$; SEGB16: $38000 \mathrm{~m}^{-2}$ ), and there were significant differences in the morphometrics of copepods from the 8 sampling stations. The average PrL of C. finmarchicus was generally smaller for samples from the continental shelf than for animals collected in slope waters (ANOVA, $F_{7,32}=10.32, \mathrm{p}<0.001$ ) (Fig. 2). However, the average PrL of animals from the northernmost shelf station (BB04) was closer to that of animals collected on the continental slope (average: $2.53 \mathrm{~mm}$ versus averages of 2.44 to $2.58 \mathrm{~mm}$ ) and significantly different (Tukey pairwise comparison, $\mathrm{p}<0.05$ ) from those collected at other locations on the shelf (average: 2.29 to $2.36 \mathrm{~mm}$ ). In addition, the average LOA was also generally smaller in individuals found on the shelf than in slope waters (ANCOVA, $F_{\text {location } 1,396}=213.4, \mathrm{p}<$ 0.001; $F_{\text {PrL 1,396 }}=405.0, \mathrm{p}<0.001$ ) (Fig. 2).

Calanus finmarchicus $\mathrm{C} 5 \mathrm{~s}$ showed relatively high levels of 14:0, 16:0, 16:1 $\omega 7,18: 1 \omega 9,20: 1 \omega 9,22: 1 \omega 11$, $16: 4 \omega 1,18: 2 \omega 6,18: 3 \omega 3,20: 4 \omega 3,20: 5 \omega 3$ and $22: 6 \omega 3$ (Table 1). Of the 59 fatty acids identified in our samples, these accounted for $65 \%$ of the total. SFA, MUFA, and PUFA represented an average of 32,28 and $39 \%$ of the total fatty acids, respectively (Table 2 ). Saturated fatty acids with chains $>\mathrm{C}_{18}$ totalled $<1 \%$ of the total fatty acids in C. finmarchicus. $\omega 3$ fatty acids accounted for a higher proportion of PUFA than $\omega 6$ fatty acids, but their relative abundance $(\Sigma \omega 3 / \Sigma \omega 6)$, an index of nutritional status, was not significantly correlated with either PrL or LOA. Bacterial fatty acid markers represented approximately $3 \%$ of the total. Bacterial fatty acid markers and MUFA were most variable, with a 

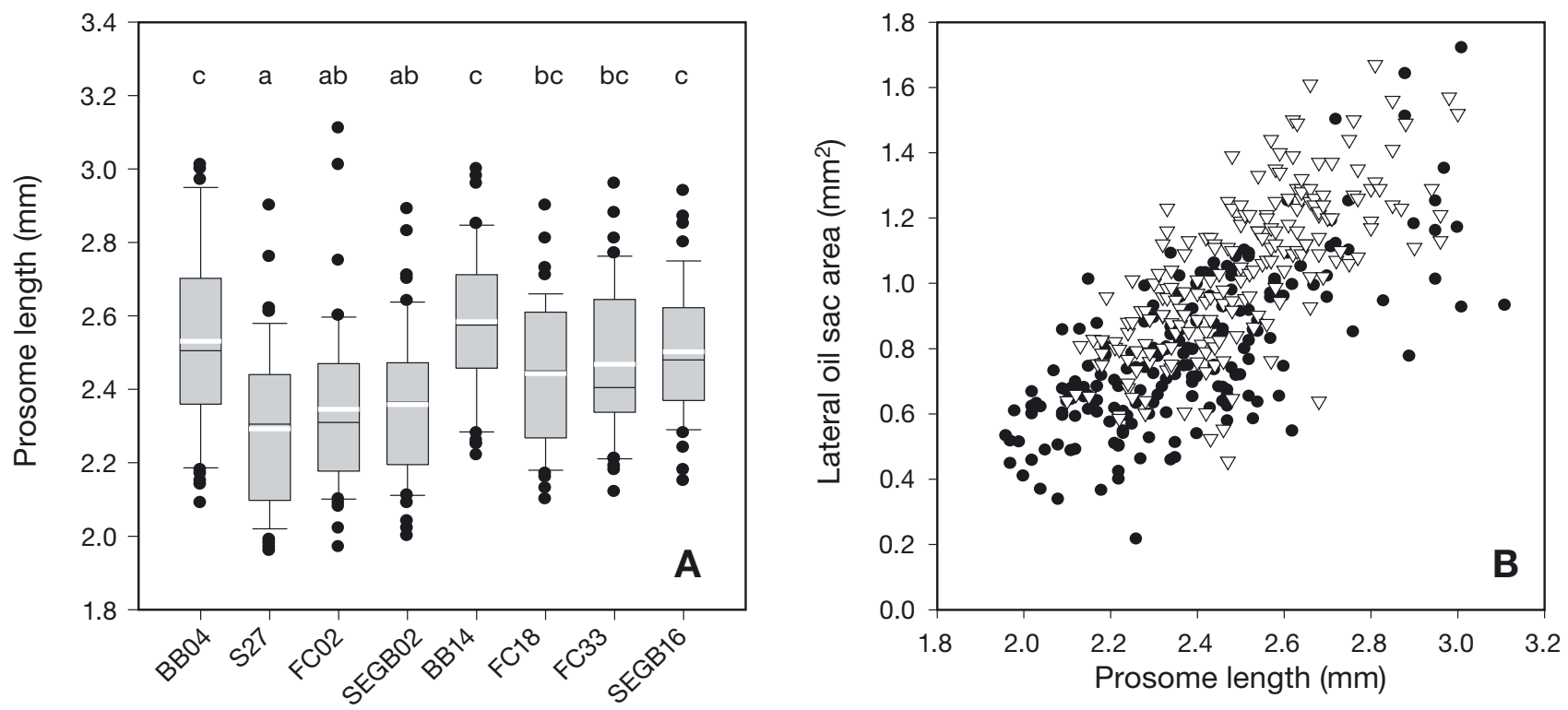

Fig. 2. Calanus finmarchicus. (A) Average prosome length ( $\mathrm{mm}$ ) of C5 copepodites from different sampling locations. Each bar represents all subsamples from each location. The thick white line represents the mean, whereas the thin black line represents the median. The lower and upper bars represent the 25th and 75th percentiles, while the whiskers represent the 10th and 90th percentiles of the distribution and closed circles represent outliers. Letters above column groups indicate similarity based on Tukey's post hoc test of means. Locations with the same letter are not significantly different based on a comparison of the mean prosome length among subsamples. (B) Individual measurements of lateral oil sac area $\left(\mathrm{mm}^{2}\right)$ in relation to prosome length (mm) for specimens collected on the continental shelf and slope. Circles and inverted triangles in Panel B represent samples collected at stations on the shelf and continental slope, respectively

Table 1. Calanus finmarchicus. Fatty acid composition (percent total fatty acids) of compounds exceeding average levels of $0.5 \%$ in C5 copepodites. Data are means and SD over all stations (sample size from the frequency of occurrence column). Also included is the Pearson product-moment correlation coefficient of the arcsine-square root transformed proportion of fatty acid composition in relation to the mean prosome length (PrL) and lateral oil sac area (LOA) of copepodites from each subsample. The 2 right-hand columns give the $\mathrm{p}$-values of the $t$-tests contrasting samples by location (shelf versus slope) and the dominant Tukey post hoc groupings of average PrL. Statistically significant $(\mathrm{p}<0.05)$ correlation coefficients and $\mathrm{p}$-values are shown in bold. Italicised values in the 2 right most columns indicate that the indices are greater in samples from the slope and in larger copepodites, respectively

\begin{tabular}{|c|c|c|c|c|c|c|c|}
\hline $\begin{array}{l}\text { Fatty } \\
\text { acid }\end{array}$ & $\begin{array}{c}\text { Mean } \\
\text { percentage }\end{array}$ & $\mathrm{SD}$ & $\begin{array}{c}\text { Frequency of } \\
\text { occurrence }\end{array}$ & $\begin{array}{l}\text { Pearson } \\
\text { correlation } \\
\text { with PrL }\end{array}$ & $\begin{array}{l}\text { Pearson } \\
\text { correlation } \\
\text { with LOA }\end{array}$ & $\begin{array}{c}\mathrm{p} \text {-value } \\
\text { of } t \text {-test } \\
\text { (shelf vs. slope) }\end{array}$ & $\begin{array}{c}\mathrm{p} \text {-value } \\
\text { of } t \text {-test } \\
\text { (size groups) }\end{array}$ \\
\hline $14: 0$ & 19.1 & 2.5 & 36 & 0.081 & 0.196 & 0.074 & 0.926 \\
\hline$i 15: 0$ & 0.5 & 0.1 & 36 & -0.579 & -0.560 & 0.130 & $<0.001$ \\
\hline $15: 0$ & 1.0 & 0.2 & 36 & -0.693 & -0.576 & 0.235 & $<0.001$ \\
\hline $16: 0$ & 11.1 & 1.2 & 36 & -0.443 & -0.225 & 0.955 & 0.010 \\
\hline $16: 1 \omega 9$ & 0.5 & 0.2 & 35 & -0.447 & -0.355 & 0.444 & 0.008 \\
\hline $16: 1 \omega 7$ & 5.8 & 1.6 & 36 & 0.543 & 0.479 & 0.253 & $<0.001$ \\
\hline $16: 1 \omega 5$ & 0.7 & 0.1 & 36 & -0.688 & -0.766 & $<0.001$ & $<0.001$ \\
\hline $16: 2 \omega 4$ & 0.8 & 0.2 & 36 & 0.092 & 0.124 & 0.894 & 0.073 \\
\hline $16: 3 \omega 4$ & 0.6 & 0.4 & 34 & 0.230 & 0.115 & 0.600 & 0.101 \\
\hline $16: 4 \omega 3$ & 0.5 & 0.2 & 36 & -0.558 & -0.566 & 0.038 & $<0.001$ \\
\hline $16: 4 \omega 1$ & 1.5 & 1.0 & 36 & 0.739 & 0.626 & 0.088 & $<0.001$ \\
\hline $18: 0$ & 0.7 & 0.2 & 36 & -0.231 & -0.303 & 0.075 & 0.009 \\
\hline $18: 1 \omega 9$ & 4.1 & 0.9 & 36 & -0.569 & -0.395 & 0.403 & 0.018 \\
\hline $18: 2 \omega 6$ & 1.2 & 0.2 & 36 & -0.247 & -0.350 & 0.184 & 0.030 \\
\hline $18: 3 \omega 3$ & 1.4 & 0.6 & 36 & -0.809 & -0.706 & 0.019 & $<0.001$ \\
\hline $18: 4 \omega 3$ & 10.8 & 3.4 & 36 & -0.677 & -0.704 & 0.001 & $<0.001$ \\
\hline 19:0 & 0.9 & 0.3 & 34 & 0.231 & 0.131 & 0.974 & 0.900 \\
\hline $20: 1 \omega 9$ & 5.2 & 2.1 & 36 & 0.669 & 0.594 & 0.020 & $<0.001$ \\
\hline $20: 4 \omega 3$ & 1.2 & 0.4 & 35 & -0.284 & -0.346 & 0.277 & 0.118 \\
\hline $20: 5 \omega 3$ & 12.2 & 1.6 & 36 & 0.644 & 0.466 & 0.450 & $<0.001$ \\
\hline $22: 1 \omega 11(13)$ & 7.6 & 2.7 & 36 & 0.592 & 0.628 & $<0.001$ & $<0.001$ \\
\hline $22: 1 \omega 9$ & 0.5 & 0.2 & 36 & 0.537 & 0.497 & 0.040 & $<0.001$ \\
\hline $22: 6 \omega 3$ & 6.5 & 1.4 & 36 & -0.569 & -0.711 & 0.001 & $<0.001$ \\
\hline
\end{tabular}


Table 2. Calanus finmarchicus. Trophic marker and summary indices of C5 copepodites. Data are means and SD averaged over all stations. MUFA: monounsaturated fatty acid; PUFA: polyunsaturated fatty acid. Other explanations as in Table 1

\begin{tabular}{|c|c|c|c|c|c|c|}
\hline $\begin{array}{l}\text { Fatty acid } \\
\text { summary } \\
\text { indices }\end{array}$ & $\begin{array}{l}\text { Mean } \\
\text { percentage } \\
\text { or ratio }\end{array}$ & $\mathrm{SD}$ & $\begin{array}{l}\text { Pearson } \\
\text { correlation } \\
\text { with PrL }\end{array}$ & $\begin{array}{l}\text { Pearson } \\
\text { correlation } \\
\text { with LOA }\end{array}$ & $\begin{array}{c}\mathrm{p} \text {-value } \\
\text { of } t \text {-test } \\
\text { (shelf vs. slope) }\end{array}$ & $\begin{array}{c}\mathrm{p} \text {-value } \\
\text { of } t \text {-test } \\
\text { (small vs. large) }\end{array}$ \\
\hline$\Sigma \omega 3$ & 33.6 & 4.8 & -0.653 & -0.743 & $<0.001$ & $<0.001$ \\
\hline$\Sigma \omega 6$ & 1.93 & 0.5 & -0.471 & -0.328 & 0.283 & 0.125 \\
\hline$\Sigma \omega 3 / \Sigma \omega 6$ & 18.0 & 3.74 & -0.055 & -0.234 & 0.287 & 0.491 \\
\hline $18: 1 \omega 9+18: 4 \omega 3$ & 14.9 & 0.04 & -0.750 & -0.727 & 0.001 & $<0.001$ \\
\hline $22: 6 \omega 3 / 20: 5 \omega 3$ & 0.54 & 0.15 & -0.723 & -0.761 & 0.002 & $<0.001$ \\
\hline $16: 1 \omega 7+16: 4 \omega 1+20: 5 \omega 3$ & 7.7 & 2.4 & 0.684 & 0.590 & 0.752 & $<0.001$ \\
\hline $16: 1 \omega 7 / 16: 0$ & 0.54 & 0.19 & 0.563 & 0.431 & 0.600 & $<0.001$ \\
\hline $16: 1 \omega 7 / 18: 4 \omega 3$ & 0.63 & 0.34 & 0.587 & 0.541 & 0.124 & $<0.001$ \\
\hline$\Sigma \mathrm{C}_{16} / \Sigma \mathrm{C}_{18}$ & 1.08 & 0.27 & 0.681 & 0.664 & 0.014 & $<0.001$ \\
\hline $\mathrm{C}_{16}$ PUFA index & 0.16 & 0.05 & 0.524 & 0.392 & 0.591 & $<0.001$ \\
\hline $18: 2 \omega 6+18: 3 \omega 3$ & 2.6 & 0.01 & -0.741 & -0.682 & 0.019 & $<0.001$ \\
\hline 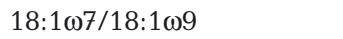 & 0.11 & 0.04 & 0.460 & 0.323 & 0.804 & 0.002 \\
\hline$\Sigma$ Bacterial & 2.9 & 0.6 & -0.417 & -0.331 & 0.883 & 0.001 \\
\hline$\Sigma$ Saturated & 32.4 & 3.2 & -0.209 & -0.027 & 0.327 & 0.159 \\
\hline$\Sigma$ MUFA & 27.7 & 5.2 & 0.602 & 0.601 & 0.005 & $<0.001$ \\
\hline$\Sigma$ PUFA & 38.9 & 4.8 & -0.549 & -0.686 & $<0.001$ & $<0.001$ \\
\hline
\end{tabular}

coefficient of variation (CV) $\sim 20 \%$, while PUFA and SFA were somewhat less variable (CV 10-12\%).

Multivariate analyses revealed a strong pattern of separation among MUFA, PUFA, SFA, bacterial fatty acid markers and $\omega 3$ PUFAs (Fig. 3). The first 2 principal components (PCs) explained a total of $92 \%$ of the variation among the 36 subsamples. MUFAs were separated from other fatty acids along the first principal

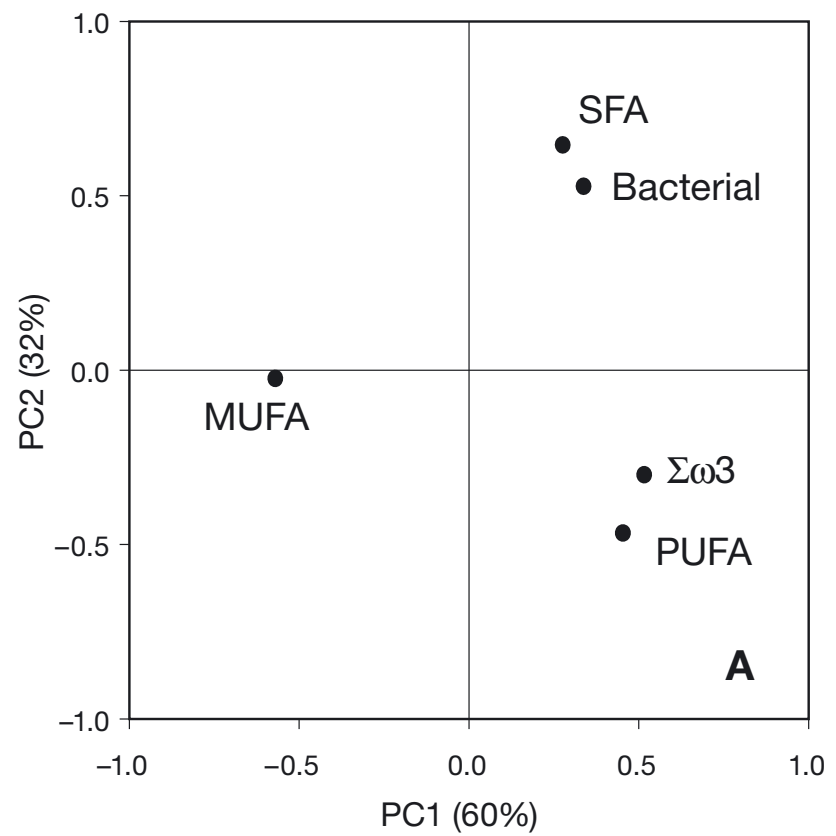

component, while PUFAs were separated from the SFAs and the bacterial fatty acid markers along the second PC. Superimposing the observations revealed a clear separation of samples from shelf and slope locations principally along the first axis, with slope samples having higher levels of MUFAs and shelf samples having greater levels of PUFAs (Table 2, Fig. 3). Separation along the first PC was significantly negatively

Fig. 3. Calanus finmarchicus. First (PC1) and second (PC2) principal components, showing the position of (A) fatty acids and (B) observations. Values in parentheses indicate the percentage of variance explained by each PC. Circles and inverted triangles in (B) represent samples collected at stations on the shelf and continental slope, respectively

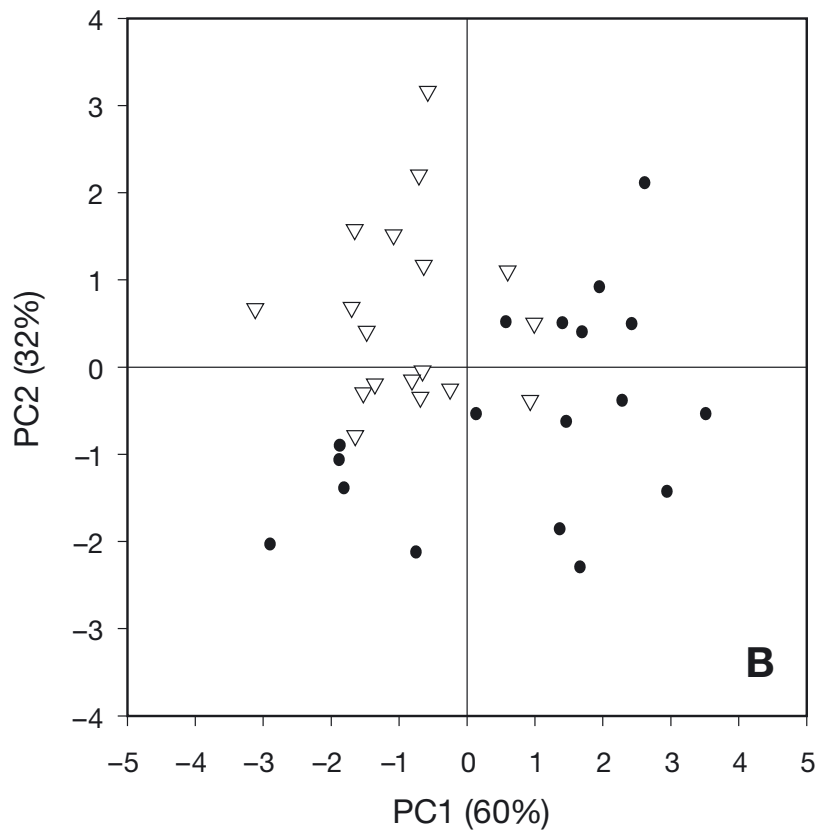


associated with average PrL $(\mathrm{r}=-0.655)$ and LOA $(\mathrm{r}=$ -0.649 ) of the copepods in each sample.

A similar separation of sites was obtained when 14 individual fatty acids ( $>1 \%$ average of total) were used in the analysis, although the overall variance explained by the first 2 PCs was reduced to $68 \%$ (Fig. 4). There was clear separation in the proportion of diatom (16:1 $\omega 7$,

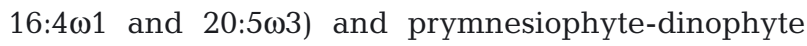
$(18: 1 \omega 9,18: 4 \omega 3$ and $22: 6 \omega 3)$ fatty acid markers along the first PC. PrL was again significantly inversely correlated with the first PC $(r=-0.745)$, positively correlated with diatom markers and negatively correlated with dinoflagellate markers (Tables 1 \& 2, Fig. 5).

Of the 25 fatty acids with average levels $>0.5 \%, 16$ were significantly correlated with average PrL: 10 negatively and 6 positively (Table 1). Similar results were obtained for LOA. In contrast, location (shelf versus slope water) only resulted in 8 significant differences, whereas 18 significant differences were obtained using the Tukey post hoc groupings that were strongly differentiated based on PrL (Table 1). These findings indicate that body size is a dominant correlate of fatty acid composition in Calanus finmarchicus.

A comparison of 4 diatom indices $(16: 1 \omega 7+16: 4 \omega 1+$ $\left.20: 5 \omega 3 ; 16: 1 \omega 7 / 16: 0 ; 16: 1 \omega 7 / 18: 4 \omega 3 ; \Sigma \mathrm{C}_{16} / \Sigma \mathrm{C}_{18}\right)$ and the $\mathrm{C}_{16}$ PUFA diatom index based on location alone gave a significant difference only for $\Sigma \mathrm{C}_{16} / \Sigma \mathrm{C}_{18}$, although differences became highly significant for all 5 when samples were grouped by the dominant Tukey post hoc groupings of average PrL by location

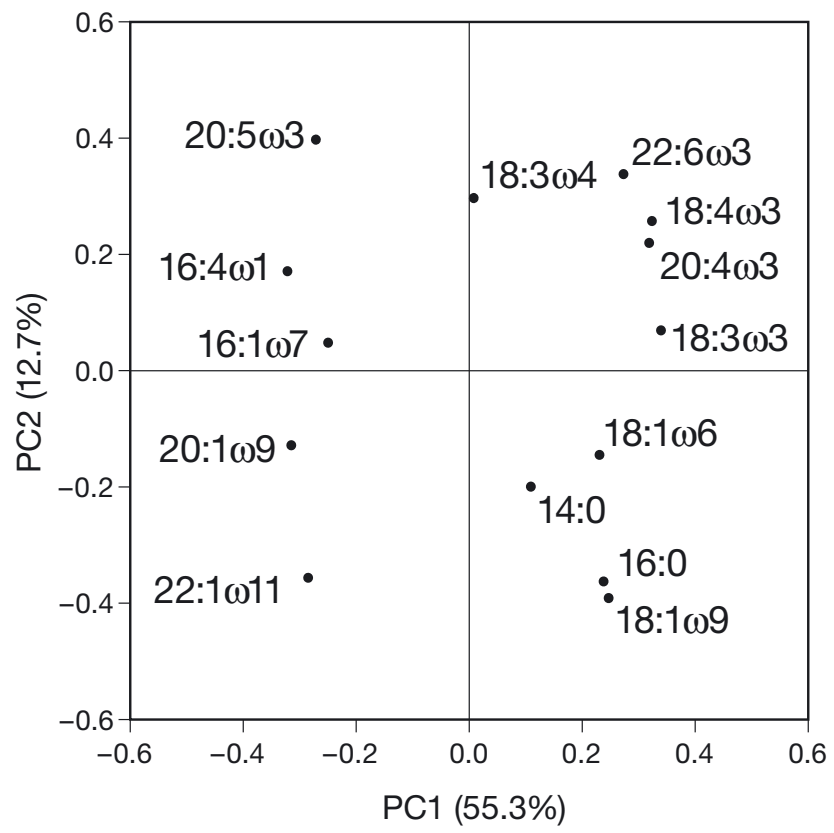

Fig. 4. First (PC1) and second (PC2) principal components, showing the position of individual fatty acids. Values in parentheses indicate the percentage of variance explained by each PC

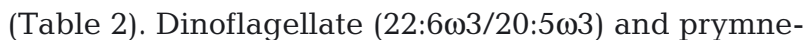
siophyte $(18: 1 \omega 9+18: 4 \omega 3)$ indices were significantly inversely correlated with PrL and LOA, and showed significant differences in groupings by location of body size (Table 2). The average proportions of diatom

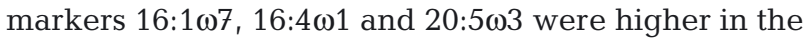
large copepod grouping by $0.0198,0.0142$ and 0.0190 , respectively, while the average proportions of the prymnesiophyte marker 18:4 103 and dinoflagellate

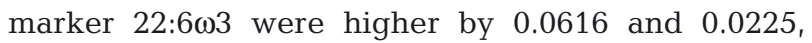
respectively, in the small copepod grouping. The aver-

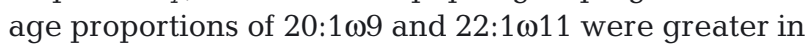
the large copepods (difference $=0.0293$ and 0.0441, respectively), as were the levels of larger energy reserves. The difference in the proportions of other fatty acids between Tukey post hoc groupings based on average PrL did not exceed 0.01. Overall, smaller C5 Calanus finmarchicus tended to have greater proportions of dinoflagellate markers, whereas diatom markers were more abundant in larger copepodites.

Calanus finmarchicus collected on the continental shelf, near the coast, had significantly higher levels of biomarkers indicative of terrestrial input in their diet, whether the groupings were based on location or size. There was a strong significant negative correlation of 18:2 $\omega 6+18: 3 \omega 3$ with both PrL and LOA (Table 2). In addition, we note a significant positive association between the index of omnivory $(18: 1 \omega 7 / 18: 1 \omega 9)$ and PrL, again presenting a strong separation among animals based on average body size.

\section{DISCUSSION}

The circulation on the Newfoundland Shelf and western Labrador Sea is dominated by the equatorward-flowing inshore and offshore branches of the Labrador Current, with some cross-shelf transport occurring through channels adjacent to major banks (Loder et al. 1998, Han et al. 2008). The pattern of satellite-derived sea surface temperature (Fig. 6) reveals that animals from northern areas on the continental shelf would have experienced lower temperatures than animals found farther south. Similarly, animals in surface waters on the continental shelf during summer and autumn would have been exposed to higher temperatures than animals in surface waters of the western Labrador Sea in spring and early summer. Therefore, animals collected in December on the southern continental shelf would have experienced higher temperatures during their development than copepods collected farther north or in offshore waters.

On the Newfoundland Shelf, the abundance of phytoplankton, particularly diatoms, is inversely related to temperature in the upper mixed layer (Pepin et 

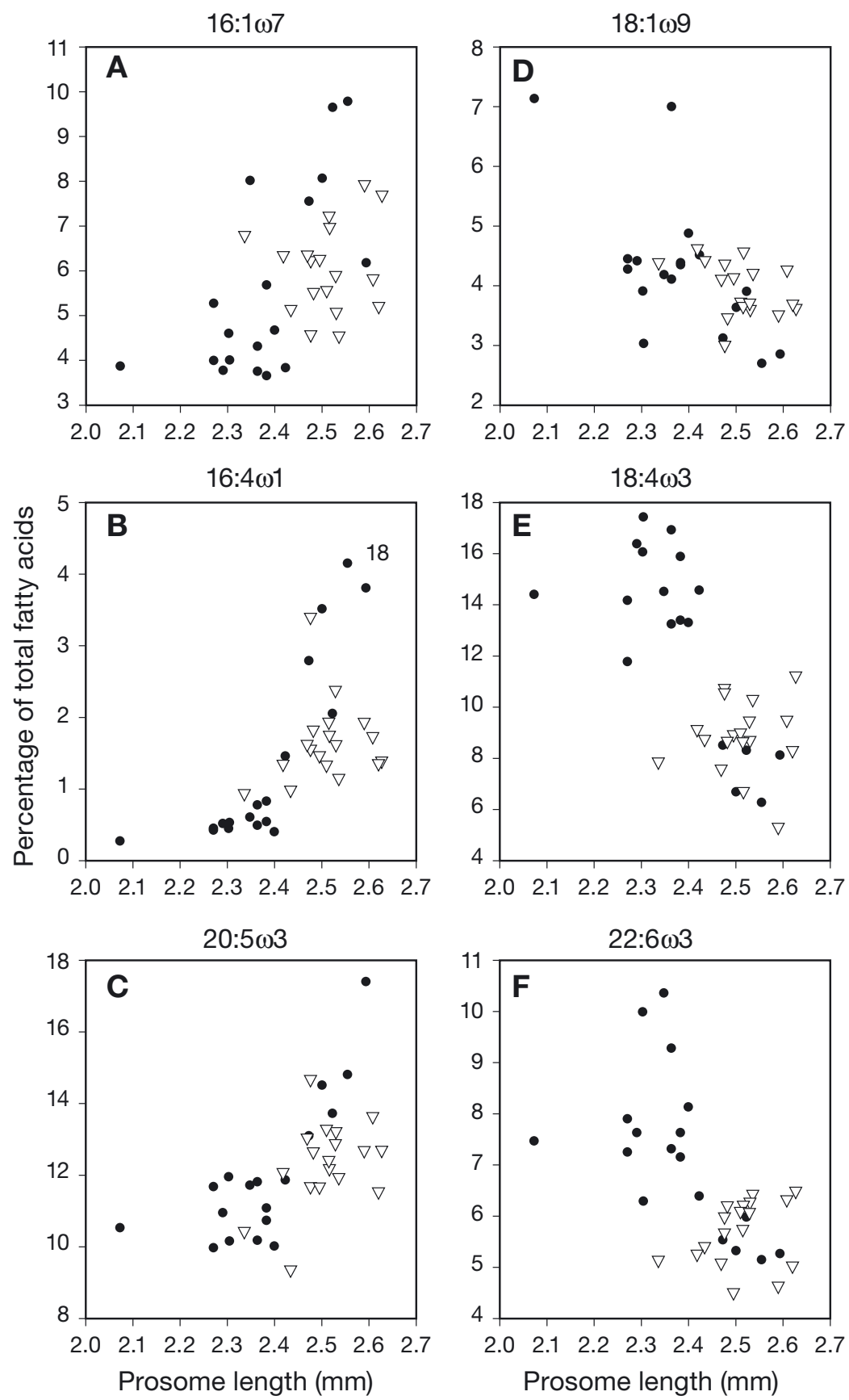

Fig. 5. Calanus finmarchicus. Percentage of total fatty acid of (A) 16:1 107 , (B)

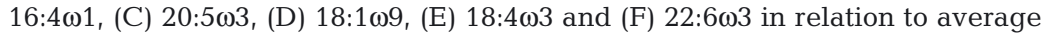
prosome length. Circles and inverted triangles in the panels represent samples collected at stations on the shelf and continental slope, respectively. Note that statistical analyses were performed on arcsine-square root transforms of proportions shown in panels

al. 2008). Diatoms are most abundant in the early spring, when temperatures begin to rise from the winter minimum, while autotrophic flagellates are present throughout the year, with minor increases in the abundance of dinoflagellates during the spring and late fall (Fig. 7). Consequently, high diatom concentrations are associated with low temperatures, and their effects on copepod growth in this region are therefore confounded. Temperature probably has the most important influence on body size (PrL) based on a laboratory study by Campbell et al. (2001). Interpretation of fatty acid composition must therefore be set against a backdrop of the seasonally co-varying effects of environmental conditions.

Pepin \& Head (2009) found that larger individuals were produced during the early part of the year, in response to the relatively low temperatures and high food concentrations. As the season progressed, the composition of animals in the deep offshore waters began to reflect a mixture of individuals that had developed at different times during the growing season. The accumulation of large energy reserves by copepods in the form of lipids has been hypothesised to play a significant role in the ability of Calanus finmarchicus to survive over-wintering periods, by contributing to buoyancy and metabolism during diapause (e.g. Irigoien 2004), and subsequently by fuelling moulting and early gonad development prior to the spring phytoplankton bloom (e.g. Plourde \& Runge 1993). Based on prior observations of the vertical distributions of $C$. finmarchicus on and off the continental shelf (Head \& Pepin 2008a, Pepin \& Head 2009), the larger animals collected at offshore sites in this study were most likely from the sub-surface layers and were most likely diapausing, whereas a large proportion of animals occurring at sites on the shelf were probably from the near surface layers and still active. At slope water stations dominated by diapausing copepods, C5 $C$. finmarchicus had larger body sizes and greater energy reserves and had apparently fed mainly on diatoms and omnivorously. By contrast, at shelf stations where a greater proportion of the population was active, individuals were small, had lower energy reserves, and had been feeding more extensively on dinoflagellates and prymnesiophytes. The relatively high proportions of energy-rich MUFAs in the larger animals may reflect the fact that they had been in dia- 


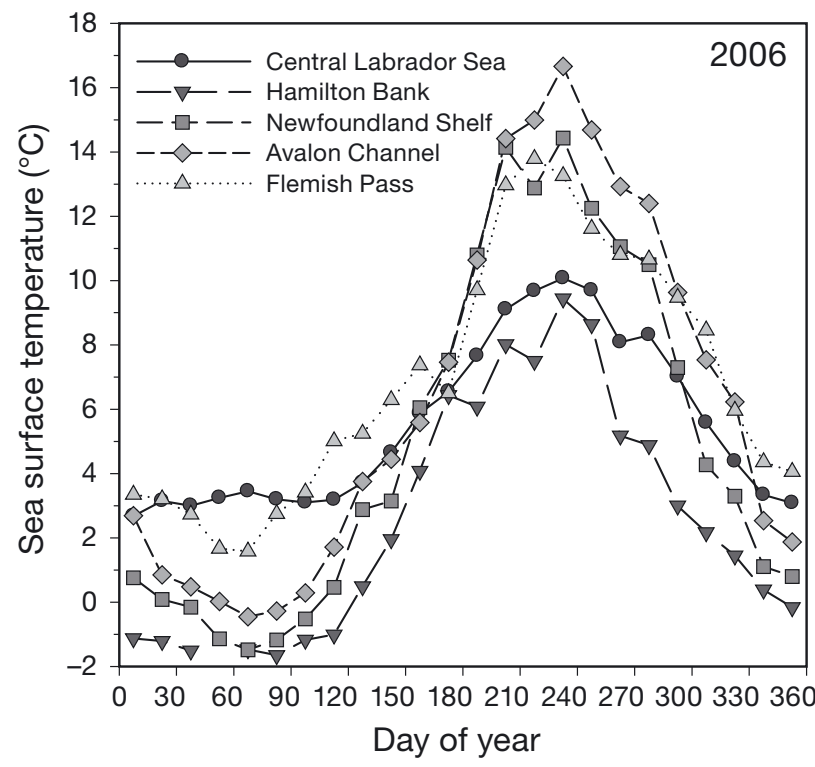

Fig. 6. Average satellite-derived sea surface temperature for 5 areas of the Newfoundland Shelf and Labrador Sea for $2 \mathrm{wk}$ intervals in 2006. Areas are shown in Fig. 1, with the exception of the site for the central Labrador Sea $\left(56^{\circ} 37.6^{\prime} \mathrm{N}\right.$, $53^{\circ} 10.1^{\prime} \mathrm{W}$ to $58^{\circ} 7.6^{\prime} \mathrm{N}, 50^{\circ} 24.9^{\prime} \mathrm{W}$ ) pause for some time and had metabolised the PUFAs that would have been ingested in their diatom diet (Kattner et al. 1989); MUFAs can be synthesised de novo by copepods and may be preferentially conserved in wax esters (Lee 1974).

The C5s analysed in this study were the survivors of Calanus finmarchicus spawned over the course of the preceding spring and summer. Madsen et al. (2001) found that diatoms were important prey for Calanus copepods during the spring phytoplankton bloom but that ciliates and heterotrophic dinoflagellates were important food sources during the post-bloom period. Our results are consistent with this if the larger animals we collected in the slope waters were spawned earlier during the year and had fed on the spring (diatom) bloom when temperatures were lower, while the smaller animals we collected on the shelf were spawned later and had fed on dinoflagellates and prymnesiophytes when temperatures were higher. It is not possible to determine the relative role of food availability versus food type on growth from this study because the effect of temperature would have had a greater influence on the overall size of copepodites and would probably also have affected their ability to store, rather than metabolise, ingested energy
Fig. 7. (A) Seasonal cycle in phytoplankton abundance (open circles) and relative taxonomic composition (proportion - solid bars) from sampling site $\mathrm{S} 27$, for the period 2000 to 2005 (P. Pepin unpublished data). (B) Seasonal cycle in upper layer temperature ( 0 to $25 \mathrm{~m}$ average; closed circles and solid line) and chlorophyll a concentration $(0$ to $50 \mathrm{~m}$ average; closed triangles and dashed line) for the same period. Sampling at that site is based on approximately bimonthly collections using ships-of-opportunity as part of an oceanographic monitoring programme

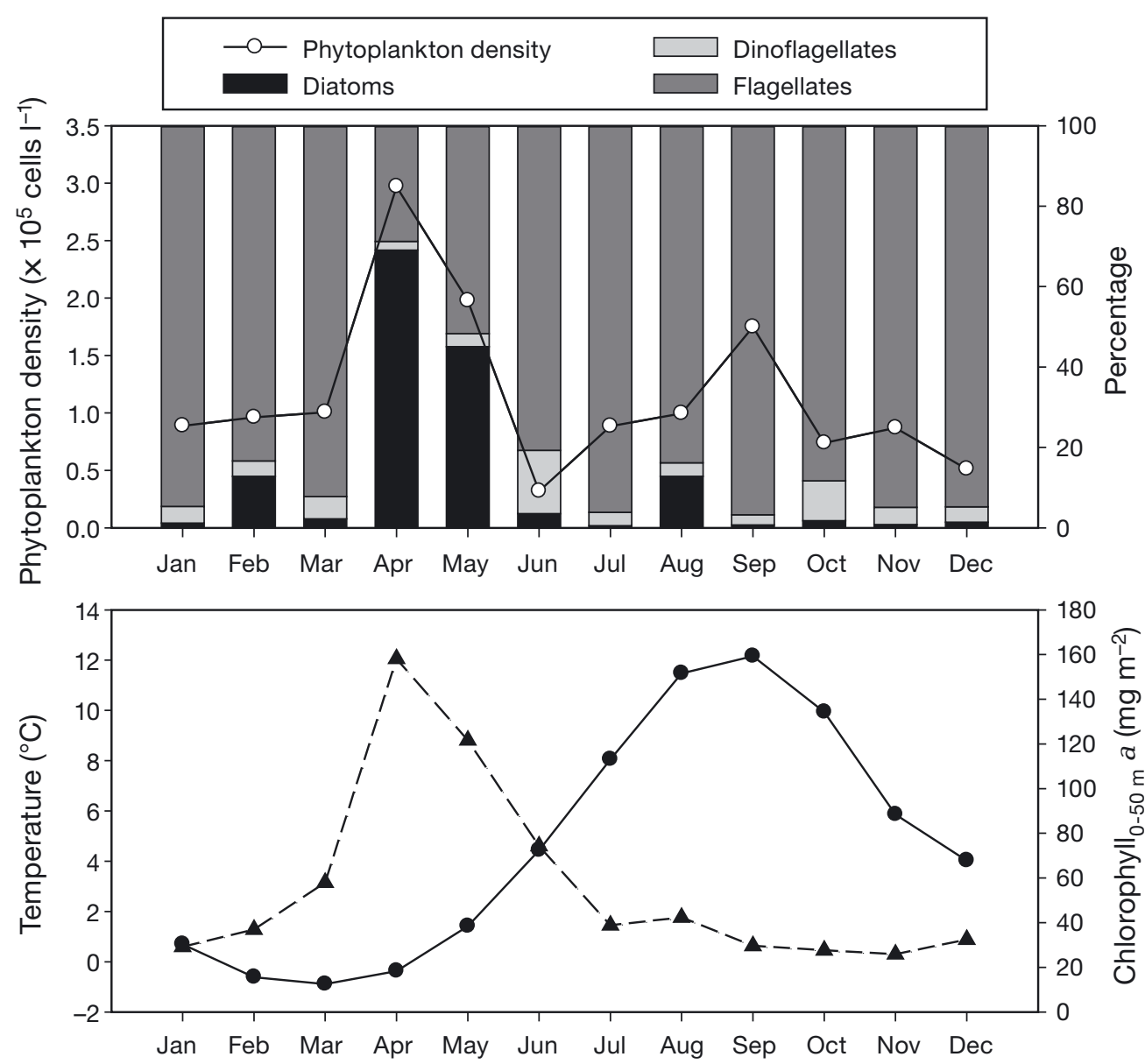


(including fatty acids). Despite smaller energy reserves and body sizes, however, the fatty acid composition of C. finmarchicus from the continental shelf was of high nutritional value (high levels of $\Sigma \omega 3$ PUFA and high docosahexaenoic acid/eicosapentaenoic acid, DHA/EPA, ratio), which might have resulted from a low intake of diatom 20:5 $\omega 3$ and preferential catabolism of non- $\omega 3$ fatty acids. This suggests that these copepods were in relatively good physiological condition, which may have allowed them to subsequently moult and reproduce, because higher DHA/EPA ratios have been linked to hatching success in Temora longicornis (Arendt et al. 2005, Evjemo et al. 2008), and high levels of PUFAs have been shown to promote egg production in C. helgolandicus (Pond et al. 1996) and C. finmarchicus (Jonasdottir et al. 2002). Indeed, there is evidence that there is successful reproduction in C. finmarchicus on the Newfoundland Shelf in fall because young stage copepodites are often found there from fall to late winter (March; Head \& Pepin 2008b).

Spatial segregation of animals based on the index of terrestrial input $(18: 2 \omega 6+18: 3 \omega 3)$ showed that animals collected west of the Grand Banks had significantly greater amounts of this tracer than larger copepods sampled farther north or in offshore waters. The differences probably reflect the greater exposure to detrital inputs from coastal environments as the animals were transported by the inner branch of the Labrador Current, with copepods from the southern coastal sites having drifted in closer proximity to the coast relative to Calanus finmarchicus that were transported by the outer branch of the current. It is possible that high levels of 18:3 $\omega 3$ could have been derived from green algae, which can have high levels of this fatty acid (Arendt et al. 2005); however, high densities of Chlorophyceae were infrequent during long-term seasonal monitoring at S27 (P. Pepin \& C. H. McKenzie unpubl. data). On the other hand, Cryptophyceae can have high proportions of 18:2 $\omega 6$ (Viso \& Marty 1993) and can be abundant during August and September (C. H. McKenzie unpubl. data), which could have contributed to the elevated levels found in copepods in the inner branch of the Labrador Current. However, compoundspecific stable isotope analyses confirmed the terres-

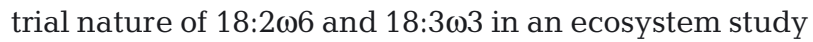
of a Newfoundland fjord (Copeman et al. 2009). The

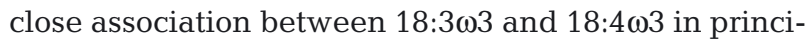
pal components analyses here and in Copeman et al. (2009) suggests that some of the $18: 403$ may be derived by desaturation of 18:3 13 .

In contrast to our observations, Heath et al. (2008) found that the highest proportion of entrants to the overwintering state in the East Greenland CurrentAtlantic area of the Irminger Sea in July/August were animals that had the highest dietary contribution of fatty acid biomarkers from dinoflagellates and the lowest from diatoms and microheterotrophs-prymnesiophytes. They argued that diatoms were probably less diagnostic of the spatial origin of copepods because of the localised nature of the blooms within the region. In the western Labrador Sea and Newfoundland Shelf, however, because of the strong association with body size, differences in fatty acid composition among collection sites are more likely to result from seasonal differences in food available to Calanus finmarchicus.

The significance of the fall generation of Calanus finmarchicus to regional population dynamics is unclear (Neuheimer et al. 2010), although autumn survival of C. finmarchicus on the Newfoundland Shelf appears to be lower than during the main spring growth period (Plourde et al. 2009). Variations in body size observed in our collections reflect the different feeding and thermal histories of individual copepods, and the combined effects of these factors could perhaps be explored using inverse modelling techniques and individual based models (e.g. Gentleman et al. 2008) so as to help establish the influence that prey type has on growth and development. Most models of C. finmarchicus dynamics to date have relied on representing prey availability in direct relation to total phytoplankton standing stock instead of a community of 2 or more taxa (e.g. Bryant et al. 1997, Speirs et al. 2006, Gentleman et al. 2008). If, however, prey type can influence growth and the accumulation of energy reserves, and thus, for example, the likelihood of entry into diapause, then models using gross measures of phytoplankton biomass may be inadequate. An improved understanding could be crucial in predicting the effects of climate change on this keystone species, since warming temperatures are likely to lead to significant changes in phytoplankton production and composition in the future (e.g. Agawin et al. 2000, Li 2009).

Acknowledgements. We thank G. Maillet, T. Shears, C. Mercer, S. Fraser, G. Redmond and J. Wells for technical assistance. The careful and detailed comments from the referees were helpful in revising the manuscript.

\section{LITERATURE CITED}

Agawin NSR, Duarte CM, Agusti S (2000) Nutrient and temperature control of the contribution of picoplankton to phytoplankton biomass and production. Limnol Oceanogr 45:591-600

Arashkevich EG, Tande KS, Pasternak AF, Ellertsen B (2004) Seasonal moulting patterns and the generation cycle of Calanus finmarchicus in the NE Norwegian Sea, as inferred from gnathobase structures, and the size of gonads and oil sacs. Mar Biol 146:119-132

> Arendt KE, Jonasdottir SH, Hansen PJ, Gaertner S (2005) Effects of dietary fatty acids on the reproductive success of the calanoid copepod Temora longicornis. Mar Biol 146: $513-530$ 
Bryant AD, Heath MR, Gurney WSG, Beare DJ, Robertson W (1997) The seasonal dynamics of Calanus finmarchicus: development of a three-dimensional structured population model and application to the northern North Sea. J Sea Res 38:361-379

Budge SM, Parrish CC (1998) Lipid biogeochemistry of plankton, settling matter and sediments in Trinity Bay, Newfoundland. II. Fatty acids. Org Geochem 29:1547-1559

Campbell RG, Wagner MM, Teegarden GJ, Boudreau CA, Durbin EG (2001) Growth and development rates of the copepod Calanus finmarchicus reared in the laboratory. Mar Ecol Prog Ser 221:161-183

Copeman LA, Parrish CC, Gregory RS, Jamieson RE, Wells J, Whiticar MJ (2009) Fatty acid biomarkers in coldwater eelgrass meadows: elevated terrestrial input to the food web of age-0 Atlantic cod Gadus morhua. Mar Ecol Prog Ser 386:237-251

Corkett CJ, McLaren IA, Sevigny JM (1986) The rearing of the marine calanoid copepods Calanus finmarchicus (Gunnerus) C. glacialis (Jaschnov) and C. hyperboreus (Kroyer) with comment on the equiproportional rule (Copepoda). Proc 2nd Int Conf Copepoda. Syllogeus 58: 539-546

Dalsgaard J, St.John M, Kattner G, Müller-Navarra D, Hagen W (2003) Fatty acid trophic markers in the pelagic marine environment. Adv Mar Biol 46:227-340

Durbin EG, Garrahan PR, Casas MC (2000) Abundance and distribution of Calanus finmarchicus on the Georges Bank during 1995 and 1996. ICES J Mar Sci 57:1664-1685

- Edvardsen A, Tande KS, Slagstad D (2003) The importance of advection on production of Calanus finmarchicus in the Atlantic part of the Barents Sea. Sarsia 88:261-273

Evjemo JO, Tokle N, Vadstein O, Olsen Y (2008) Effect of essential dietary fatty acids on egg production and hatching success of the marine copepod Temora longicornis. J Exp Mar Biol Ecol 365:31-37

> Gentleman WC, Neuheimer AB, Campbell RG (2008) Modelling copepod development: current limitations and a new realistic approach. ICES J Mar Sci 65:399-413

Gislason A, Astthorsson OS (1996) Seasonal development of Calanus finmarchicus along an inshore-offshore gradient southwest of Iceland. Ophelia 44:71-84

Han G, Lu Z, Wang Z, Helbig J, Chen N, deYoung B (2008) Seasonal variability of the Labrador Current and shelf circulation off Newfoundland. J Geophys Res 113:C10013 doi:10.1029/2007JC004376

Harms IH, Heath MR, Bryant AD, Backhaus JO, Hainbucher DA (2000) Modelling the Northeast Atlantic circulation: implications for the spring invasion of shelf regions by Calanus finmarchicus. ICES J Mar Sci 57:1694-1707

Head EJH, Pepin P (2008a) Variations in overwintering depth distributions of Calanus finmarchicus in the slope waters of the NW Atlantic continental shelf and the Labrador Sea. J Northwest Atl Fish Sci 39:49-69

Head EJH, Pepin P (2008b) Seasonal cycles of Calanus finmarchicus abundance at fixed time-series stations on the Scotian and Newfoundland shelves (1999-2006). AZMP Bull 7:17-20. Available at www.meds-sdmm.dfo-mpo.gc. ca/isdm-gdsi/azmp-pmza/index-eng.html

Head EJH, Harris LR, Campbell RW (2000) Investigations on the ecology of Calanus spp. in the Labrador Sea. I. Relationship between the phytoplankton bloom and reproduction and development of Calanus finmarchicus in spring. Mar Ecol Prog Ser 193:53-73

Head EJH, Melle W, Pepin P, Bagøien E, Brøms CTA (in press) A comparative study of the ecology of Calanus finmarchicus in the Labrador and Norwegian seas. Prog Oceanogr
Heath MR, Boyle PR, Gislason A, Gurney WSG and others (2004) Comparative ecology of over-wintering Calanus finmarchicus in the northern North Atlantic, and implications for life-cycle patterns. ICES J Mar Sci 61:698-708

> Heath MR, Rasmussen J, Ahmed Y, Allen J and others (2008) Spatial demography of Calanus finmarchicus in the Irminger Sea. Prog Oceanogr 76:39-88

Irigoien X (2004) Some ideas about the role of lipids in the life cycle of Calanus finmarchicus. J Plankton Res 26:259-263

Johnson CL, Pringle J, Changsheng C (2006) Transport and retention of dormant copepods in the Gulf of Maine. Deep-Sea Res II 53:2520-2536

Johnson CL, Leising AW, Runge JA, Head EJH, Pepin P, Plourde S, Durbin EG (2008) Characteristics of Calanus finmarchicus dormancy patterns in the northwest Atlantic. ICES J Mar Sci 65:339-350

Jonasdottir SH, Gudfinnsson HG, Gislason A, Astthorsson OS (2002) Diet composition and quality for Calanus finmarchicus egg production and hatching success off southwest Iceland. Mar Biol 140:1195-1206

Kattner G, Hirche HJ, Krause M (1989) Spatial variability in lipid composition of calanoid copepods from Fram Strait, the Arctic. Mar Biol 102:473-480

Lee RF (1974) Lipid composition of the copepod Calanus hyperboreus from the Arctic ocean: changes with depth and season. Mar Biol 26:313-318

Li WKW (2009) Plankton populations and communities. In: Whitman JD, Roy K (eds) Marine macroecology. University of Chicago Press, Chicago, IL, p 29-64

Loder JW, Petrie BD, Gawakiewicz G (1998) The coast ocean off northeastern North America: a large-scale view. In: Bring KH, Robinson AR (eds) The global coastal ocean: regional studies and synthesis, Vol 11. John Wiley, Hoboken, NJ, p 105-133

Madsen S, Nielsen T, Hansen B (2001) Annual population development and production by Calanus finmarchicus, $C$. glacialis and C. hyperboreus in Disko Bay, western Greenland. Mar Biol 138:1121-1130

> Mauchline J (ed) (1998) The biology of calanoid copepods. Adv Mar Biol 33:1-710

> McLaren IA, Head EJH, Sameoto DD (2001) Life cycles and seasonal distributions of Calanus finmarchicus on the central Scotian Shelf. Can J Fish Aquat Sci 58:659-670

Milke LM, Bricelj VM, Parrish CC (2004) Growth of postlarval sea scallops, Placopecten magellanicus, on microalgal diets, with emphasis on the nutritional role of lipids and fatty acids. Aquaculture 234:293-317

> Miller CB, Morgan CA, Prahl FG, Sparrow MA (1998) Storage lipids of the copepod Calanus finmarchicus from Georges Bank and the Gulf of Maine. Limnol Oceanogr 43:488-497

Miller CB, Crain JA, Morgan CA (2000) Oil storage variability in Calanus finmarchicus. ICES J Mar Sci 57:1786-1799

> Neuheimer AB, Gentleman WC, Pepin P, Head EJH (2010) How to build and use individual-based models (IBMs) as hypothesis testing tools. J Mar Syst 81:122-133

Parrish CC (1999) Determination of total lipid, lipid classes, and fatty acids in aquatic samples. In: Arts MT, Wainman BC (eds) Lipids in freshwater ecosystems. SpringerVerlag, New York, NY, p 4-20

Parrish CC, Thompson RJ, Deibel D (2005) Lipid classes and fatty acids in plankton and settling matter during the spring bloom in a cold ocean coastal environment. Mar Ecol Prog Ser 286:57-68

> Pasternak A, Arashkevich E, Tande K, Falkenhaug T (2001) Seasonal changes in feeding, gonad development and lipid stores in Calanus finmarchicus and C. hyperboreus from Malangen, northern Norway. Mar Biol 138:1141-1152 
Pepin P, Head EJH (2009) Seasonal and depth-dependent variations in the size and lipid contents of stage 5 copepodites of Calanus finmarchicus in the waters of the Newfoundland Shelf and the Labrador Sea. Deep-Sea Res I 56: 989-1002

Pepin P, Maillet GL, Fraser S, Lane D (2003) Biological and chemical oceanographic conditions on the Newfoundland Shelf during 2002. Res Doc 2003/019. Canadian Science Advisory Secretariat, Ottawa

Pepin P, Maillet GL, Fraser S, Shears TH, Redmond G (2008) Biological and chemical oceanographic conditions on the Newfoundland Shelf during 2007. Res Doc 2008/034. Canadian Science Advisory Secretariat, Ottawa

Planque B, Batten SD (2000) Calanus finmarchicus in the North Atlantic: the year of Calanus in the context of interdecadal change. ICES J Mar Sci 57:1528-1535

Plourde S, Runge JA (1993) Reproduction of the planktonic copepod Calanus finmarchicus in the lower St. Lawrence Estuary: relation to the cycle of phytoplankton production as evidence for a Calanus pump. Mar Ecol Prog Ser 102: 217-227

Plourde S, Joly P, Runge JA, Zakardjian B, Dodson JJ (2001) Life cycle of Calanus finmarchicus in the lower St. Lawrence Estuary: the imprint of circulation and late timing of the spring phytoplankton bloom. Can J Fish Aquat Sci 58:647-658

Plourde S, Pepin P, Head EJH (2009) Mortality, survival and recruitment of Calanus finmarchicus across the Atlantic Zonal Monitoring Program region, Northwest Atlantic. ICES J Mar Sci 66:1942-1958

Editorial responsibility: Matthias Seaman, Oldendorf/Luhe, Germany
Pond D, Harris R, Head R, Harbour D (1996) Environmental and nutritional factors determining seasonal variability in the fecundity and egg viability of Calanus helgolandicus in coastal waters off Plymouth, UK. Mar Ecol Prog Ser 143: $45-63$

Sargent JR (1995) Origins and functions of egg lipids: nutritional implications. In: Bromage NR, Roberts RJ (eds) Broodstock management and egg and larval quality. Blackwell Science, Oxford, p 353-372

Sargent JR, Falk-Petersen S (1988) The lipid biochemistry of calanoid copepods. Hydrobiologia 167-168:101-114

Shields RJ, Bell JG, Luizi FS, Gara B, Bromage NR, Sargent JR (1999) Natural copepods are superior to enriched Artemia nauplii as feed for halibut larvae (Hippoglossus hippoglossus) in terms of survival, pigmentation and retinal morphology: relation to dietary essential fatty acids. J Nutr 129:1186-1194

Speirs DC, Gurney WSG, Heath MR, Horbelt W, Wood SN, De Cuevas BA (2006) Ocean-scale modelling of the distribution, abundance, and seasonal dynamics of the copepod Calanus finmarchicus. Mar Ecol Prog Ser 313:173-192

Stuart V, Sathyendranath S, Head EJH, Platt T, Irwin B, Maass H (2000) Bio-optical characteristics of diatom and prymnesiophyte populations in the Labrador Sea. Mar Ecol Prog Ser 201:91-106

Torgersen T, Huse G (2005) Variability in retention of Calanus finmarchicus in the Nordic Seas. ICES J Mar Sci 62: 1301-1309

> Viso AC, Marty JC (1993) Fatty acids from 28 marine microalgae. Phytochemistry 34:1521-1533

Submitted: February 7, 2010; Accepted: November 24, 2010 Proofs received from author(s): January 30, 2011 